\title{
Genetic diversity among accessions of sacha inchi (Plukenetia volubilis) by phenotypic characteristics analysis
}

\author{
Haroldo Silva RODRIGUES ${ }^{1}$, Aluízio BORÉM ${ }^{1}$, Mágno Sávio Ferreira VALENTE2², Maria Teresa Gomes LOPES ${ }^{2}$, \\ Cosme Damiāo CRUZ ${ }^{1}$, Francisco Célio Maia CHAVES³ ${ }^{3}$ Caroline de Souza BEZERRA² \\ ' Universidade Federal de Viçosa, Avenida PH Rolfs s/n, CEP 36570-000, Viçosa, MG, Brasil \\ 2 Universidade Federal do Amazonas, Avenida General Rodrigo Octávio 6200, CEP 69077-000, Manaus, AM, Brasil \\ ${ }^{3}$ Empresa Brasileira de Pesquisa Agropecuária - Embrapa, Rodovia AM-10, Km 29, CEP 69010-970, Manaus, AM, Brasil \\ *Corresponding author: magnosavio@yahoo.com.br
}

\section{ABSTRACT}

Sacha inchi (Plukenetia volubilis) is native to the Amazon region and has a high seed content of mono and polyunsaturated fatty acids, making it interesting for the pharmaceutical and cosmetic industry. The purpose of this study was to analyze the genetic diversity and describe the accessions based on phenotypic characteristics. Fruits and seeds of 25 accessions from the sacha inchi genebank of Embrapa Amazônia Ocidental in Manaus, Amazonas state, were sampled and biometrically measured. The data were subjected to analysis of variance, Mahalanobis distance, canonical correlation, and genetic diversity among and within by analysis of molecular variance (AMOVA). There were significant differences among the means of the analyzed traits, but no significant canonical correlation for the groups of traits. According to AMOVA, approximately $60 \%$ of the observed variation is within accessions. The results showed variability among accessions and that the variation within accessions should be explored to obtain best results in breeding programs.

KEYWORDS: Euphorbiaceae, biometrics, Amazon region, genetic resources

\section{Diversidade genética entre acessos de sacha inchi (Plukenetia volubilis) por análise de características fenotípicas}

\section{RESUMO}

Sacha inchi (Plukenetia volubilis) é nativa da regiáo amazônica e suas sementes tem um alto teor de ácidos graxos mono e poliinsaturados, tornando-a interessante para a indústria farmacêutica e cosmética. O objetivo deste estudo foi analisar a diversidade genética e caracterizar os acessos com base em características fenotípicas. Foi realizada coleta e biometria de frutos e sementes de 25 acessos do banco de germoplasma de sacha inchi da Embrapa Amazônia Ocidental em Manaus-AM. Os dados foram submetidos a análise de variância, distância de Mahalanobis, correlaçáo canônica e diversidade genética por análise de variância molecular (AMOVA). Houve diferenças significativas entre as médias das variáveis analisadas, contudo, não houve correlação canônica significativa para os grupos de variáveis. De acordo com AMOVA, aproximadamente $60 \%$ da variação observada está dentro de acessos. Os resultados mostram variabilidade entre acessos, sendo importante explorar a variação intra-acessos para obter melhores resultados em programas de melhoramento.

PALAVRAS-CHAVE: Euphorbiaceae, biometria, Amazônia, recurso genético 
Sacha inchi, Plukenetia volubilis L. (Euphorbiaceae), is a crop native to the Amazon region that has potential use in the pharmaceutical and cosmetic industries (FollegattiRomero et al. 2009). It is a semi-perennial, woody climber, and produces fruit capsules with $3-5 \mathrm{~cm}$ in diameter, usually tetralobulate, but ranging from five to seven lobes, with one oilseed per lobe and the seeds weigh between 0.8 and $1.4 \mathrm{~g}$ and contain about $54 \%$ oil and $27 \%$ protein (Follegatti-Romero et al. 2009). The oil contains high levels of unsaturated fatty acids and can reach up to $93 \%$ of the total oil (Follegatti-Romero et al. 2009).

The expansion of agriculture and urbanization borders onto the natural habitat of wild plant species, and the replacement of domestic cultivars and local races (landraces) result in erosion of the genetic diversity of native plant species or their extinction (Villalobos et al. 1991). The preservation of the full genetic variability of a species in a genebank is a possibility to avoid the loss of these genetic resources. To be able to exploit the genetic diversity available in a genebank, the accessions must be characterized and documented so that breeders can identify useful accessions for breeding programs (Valente et al. 2017).

Although the composition and properties of sacha inchi are relatively well-known, there is few information in the literature on its cultivation and genetic diversity (Valente et al. 2017). The purpose of this study was to quantify the genetic diversity among sacha inchi genotypes in the genebank of Embrapa Amazônia Ocidental.

The sacha inchi genebank maintained in the medicinal plant sector of Embrapa Amazônia Ocidental, in Manaus, state of Amazonas, currently comprises 37 accessions collected in the state of Amazonas, of which 25 were collected in the interior of the state in the same location and the other 12 at the locality of Nova Jerusalém, in the municipality of Careiro Castanho (3³1'45.0”S 59049'07.9”W).

Among all components of the genebank, the 25 found in the interior of the state were in the reproductive stage for more than one year and were therefore included in the analysis, while the others had been introduced recently and were still in a vegetative stage. The genebank was divided into two areas (Area 1 and Area 2), represented in the identification code of each accession as $\mathrm{A} 1$ and $\mathrm{A} 2$, respectively.

Five fruits per accession were collected. The morphological analysis was carried out with dry fruits on shade. The number of lobes per fruit, fruit weight, fruit length, fruit height, and number of seeds per fruit were assessed. The fruit weight and height traits were determined by gravimetry on an electronic scale and with a digital caliper, respectively. The fruit length was also determined by digital caliper, measuring the greatest distance (fruit length 1) and the shortest distance (fruit length 2) between pairs of lobes. The seeds were removed from each fruit and the weight, diameter and length of each seed were measured. The ratios of seed weight to fruit weight and to the number of seeds per lobe were were calculated to determine seed yield.

To estimate the genetic distance between accessions, analysis of variance was performed in a completely randomized design, where accessions were considered the source of variation and each fruit one replication (Lyra et al. 2012). The means of all accessions were grouped by the method of Scott-Knott at 5\% probability and the dissimilarity matrix obtained by calculating the generalized distance of Mahalanobis. The dissimilarity matrix was used in the construction of the dendrogram by the hierarchical method of mean linkage between groups (UPGMA).

The relation among the fruit- and seed-related traits was estimated using canonical correlation. The traits were divided into two groups, where group I consisted of the traits seed weight, seed diameter and seed length, and group II comprised the traits number of lobes per fruit, fruit weight, fruit height and fruit length 1 . The traits fruit length 2 and yield were removed from the analysis because they showed multicollinearity with the seed weight and seed diameter. The diversity among and within accessions was also assessed by molecular analysis of variance (AMOVA). All statistical analyses were performed with software GENES (Cruz 2013).

All traits differed among each other by at least one mean according to the F test, where all mean squares were significant. The grouping by Scott Knott test (Table 1) showed the formation of clusters for all analyzed traits, including the number of lobes per fruit, which had a low amplitude among means, yet formed two significant different groups, whith only four accessions assigned to group a. Fruit weight formed four groups, where group a consisted of seven accessions, while group $d$, comprising the lowest means, contained only three accessions. Fruit length 2 was more variable than fruit length 1 , forming four groups. Due to the uneven form of the fruit of sacha inchi, we chose to take two length measurements. For this purpose, the methodology used in this study, length 1 and length 2, proved appropriate and efficient to group means of genotypes. The values of fruit height had a considerable range among assessions, resulting in the formation of four groups, where it is notable that group a contained only one accession, and group c contained 15 accessions. Seed weight and total seed weight had means from 1.22 to 0.70 and 4.87 to 2.80 , respectively, and the largest value approximately doubled the lowest. Seed diameter and seed length also varied greatly. The accession A1M11 reached the highest mean (0.63) for yield, i.e., this accession is expected to produce around $0.63 \mathrm{~g}$ of seed for each gram of fruit.

The analysis using the Mahalanobis distance resulted in three groups, indicating low genetic diversity among accessions (Figure 1). The cutting point was set at $58.61 \%$, estimated by the Mojema method. 
Table 1. Mean grouping of Scott-Knott $(\alpha=5 \%)$ for 10 traits evaluated in 25 accessions of sacha inchi, Plukenetia volublilis contained in the genebank of Embrapa Amazônia Ocidental.

\begin{tabular}{|c|c|c|c|c|c|c|c|c|c|c|}
\hline Accession & $\begin{array}{l}\text { Lobes } \\
\text { per fruit } \\
\text { (n) }\end{array}$ & $\begin{array}{l}\text { Fruit } \\
\text { weight } \\
\text { (g) }\end{array}$ & $\begin{array}{c}\text { Fruit } \\
\text { length } 1 \\
(\mathrm{~mm}) \\
\end{array}$ & $\begin{array}{c}\text { Fruit } \\
\text { length } 2 \\
(\mathrm{~mm}) \\
\end{array}$ & $\begin{array}{c}\text { Fruit } \\
\text { height } \\
(\mathrm{mm}) \\
\end{array}$ & $\begin{array}{c}\text { Seed } \\
\text { Weight } \\
(\mathrm{g})\end{array}$ & $\begin{array}{c}\text { Seed } \\
\text { diameter } \\
(\mathrm{mm})\end{array}$ & $\begin{array}{c}\text { Seed } \\
\text { length } \\
(\mathrm{mm}) \\
\end{array}$ & $\begin{array}{c}\text { Total seed } \\
\text { weight } \\
\text { (g) }\end{array}$ & $\begin{array}{c}\text { Yield } \\
\text { (g seed } \\
\text { per g fruit) }\end{array}$ \\
\hline A1M01 & $4.0 \mathrm{~b}$ & $9.26 b$ & $39.94 \mathrm{c}$ & $40.94 \mathrm{C}$ & $21.54 b$ & $0.79 c$ & $14.03 \mathrm{~d}$ & $7.74 b$ & $3.15 c$ & $0.34 b$ \\
\hline A1M02 & $4.0 \mathrm{~b}$ & $8.66 b$ & $47.31 \mathrm{a}$ & $47.30 \mathrm{~b}$ & $19.05 c$ & $1.16 \mathrm{a}$ & $16.52 \mathrm{c}$ & 8.77 a & $4.65 a$ & $0.55 \mathrm{a}$ \\
\hline A1M03 & $4.0 \mathrm{~b}$ & $8.94 b$ & $43.62 b$ & $45.01 \mathrm{~b}$ & $21.75 b$ & $0.81 \mathrm{c}$ & $16.19 \mathrm{c}$ & $8.39 a$ & $3.26 c$ & $0.37 b$ \\
\hline A1M04 & $4.6 \mathrm{a}$ & $8.70 \mathrm{~b}$ & $44.54 \mathrm{a}$ & $44.78 b$ & $19.28 c$ & $0.81 \mathrm{c}$ & $15.60 \mathrm{c}$ & $7.68 b$ & $3.23 c$ & $0.37 b$ \\
\hline A1M05 & $4.2 \mathrm{~b}$ & $9.93 \mathrm{a}$ & $39.20 \mathrm{c}$ & $39.76 d$ & $25.10 \mathrm{a}$ & $1.19 a$ & $16.41 \mathrm{c}$ & $8.92 \mathrm{a}$ & $4.74 \mathrm{a}$ & $0.50 \mathrm{a}$ \\
\hline A1M06 & $4.0 \mathrm{~b}$ & $6.30 d$ & $43.40 \mathrm{~b}$ & $43.25 c$ & $20.00 c$ & $0.74 c$ & $13.92 \mathrm{~d}$ & $7.49 b$ & $2.97 c$ & $0.49 a$ \\
\hline A1M07 & $4.0 \mathrm{~b}$ & $10.45 a$ & $47.59 \mathrm{a}$ & $47.30 \mathrm{~b}$ & $19.89 c$ & $1.11 \mathrm{a}$ & 19.92 a & $8.77 a$ & $4.42 \mathrm{a}$ & $0.42 b$ \\
\hline A1M08 & $4.2 \mathrm{~b}$ & $9.97 a$ & $48.03 \mathrm{a}$ & $47.97 a$ & $21.22 b$ & $0.95 b$ & $17.29 \mathrm{~b}$ & $8.16 b$ & $3.79 b$ & $0.38 \mathrm{~b}$ \\
\hline A1M09 & $4.0 \mathrm{~b}$ & $8.60 \mathrm{~b}$ & $46.44 a$ & $45.60 \mathrm{~b}$ & $18.73 c$ & $0.94 b$ & $16.17 \mathrm{c}$ & $8.17 b$ & $3.77 b$ & $0.44 b$ \\
\hline A1M10 & $4.0 \mathrm{~b}$ & $10.16 \mathrm{a}$ & $48.80 \mathrm{a}$ & $47.91 \mathrm{a}$ & $22.97 \mathrm{~b}$ & $1.22 \mathrm{a}$ & $16.87 \mathrm{C}$ & $8.52 \mathrm{a}$ & $4.87 a$ & $0.48 \mathrm{a}$ \\
\hline A1M11 & $4.0 \mathrm{~b}$ & $7.14 \mathrm{C}$ & $48.24 \mathrm{a}$ & $47.92 \mathrm{a}$ & $20.43 c$ & $1.11 \mathrm{a}$ & $20.13 \mathrm{a}$ & $8.08 b$ & $4.44 \mathrm{a}$ & $0.63 \mathrm{a}$ \\
\hline $\mathrm{A} 1 \mathrm{M} 12$ & $4.0 \mathrm{~b}$ & 9.89 a & 48.97 a & 49.68 a & $22.43 b$ & $1.01 \mathrm{~b}$ & $16.05 \mathrm{C}$ & $7.93 b$ & $4.04 b$ & $0.41 \mathrm{~b}$ \\
\hline A1M13 & $4.0 \mathrm{~b}$ & $10.91 \mathrm{a}$ & $49.66 \mathrm{a}$ & $49.72 \mathrm{a}$ & $20.17 c$ & $1.02 b$ & $18.56 \mathrm{~b}$ & $8.23 b$ & $4.09 b$ & $0.38 b$ \\
\hline A1M14 & $4.0 \mathrm{~b}$ & $9.01 \mathrm{~b}$ & $49.62 \mathrm{a}$ & $49.46 \mathrm{a}$ & $22.85 b$ & $1.08 \mathrm{a}$ & 17.71 b & $8.39 a$ & $4.32 \mathrm{a}$ & $0.48 \mathrm{a}$ \\
\hline A1M15 & $4.0 \mathrm{~b}$ & $5.98 \mathrm{~d}$ & $41.34 b$ & $42.18 \mathrm{c}$ & $18.35 c$ & $0.75 c$ & $13.91 \mathrm{~d}$ & $7.90 \mathrm{~b}$ & $3.01 c$ & $0.51 \mathrm{a}$ \\
\hline A2M01 & $4.2 \mathrm{~b}$ & $7.91 \mathrm{C}$ & 38.07 c & $37.31 \mathrm{~d}$ & $16.75 c$ & $1.03 \mathrm{~b}$ & $15.76 \mathrm{C}$ & 8.48 a & $4.10 \mathrm{~b}$ & $0.52 \mathrm{a}$ \\
\hline A2M02 & $4.0 \mathrm{~b}$ & $6.30 d$ & $42.75 b$ & $42.95 \mathrm{C}$ & $18.05 c$ & $0.79 c$ & $14.47 d$ & $7.77 b$ & $3.15 c$ & $0.50 \mathrm{a}$ \\
\hline A2M03 & $4.2 \mathrm{~b}$ & $8.55 b$ & $45.51 \mathrm{a}$ & $45.68 \mathrm{~b}$ & $19.66 \mathrm{c}$ & $0.89 c$ & $14.72 \mathrm{~d}$ & $7.96 \mathrm{~b}$ & $3.55 c$ & $0.42 \mathrm{~b}$ \\
\hline A2M04 & $4.5 \mathrm{a}$ & $8.72 b$ & $43.06 \mathrm{~b}$ & $42.36 c$ & $18.36 \mathrm{c}$ & $1.16 \mathrm{a}$ & $16.04 c$ & 8.69 a & $4.63 \mathrm{a}$ & $0.54 \mathrm{a}$ \\
\hline A2M05 & $4.0 \mathrm{~b}$ & $7.87 \mathrm{c}$ & $39.23 c$ & $39.59 d$ & $17.69 c$ & $1.00 \mathrm{~b}$ & $14.20 \mathrm{~d}$ & $8.50 \mathrm{a}$ & $3.99 b$ & $0.51 \mathrm{a}$ \\
\hline A2M06 & $4.6 \mathrm{a}$ & $7.32 \mathrm{C}$ & $41.39 b$ & $43.07 \mathrm{c}$ & $19.21 \mathrm{C}$ & $0.70 \mathrm{c}$ & $15.09 \mathrm{~d}$ & $7.81 \mathrm{~b}$ & $2.80 \mathrm{C}$ & $0.40 \mathrm{~b}$ \\
\hline A2M07 & $4.0 \mathrm{~b}$ & $8.16 c$ & $46.91 \mathrm{a}$ & $46.81 \mathrm{~b}$ & $20.74 b$ & $0.93 \mathrm{~b}$ & $15.15 d$ & $8.06 \mathrm{~b}$ & $3.72 b$ & $0.46 \mathrm{~b}$ \\
\hline A2M08 & $4.4 \mathrm{a}$ & $9.42 b$ & 46.78 a & $46.69 \mathrm{~b}$ & $22.02 \mathrm{~b}$ & $0.99 \mathrm{~b}$ & $16.15 \mathrm{c}$ & 8.39 a & $3.95 b$ & $0.43 b$ \\
\hline A2M09 & $4.0 \mathrm{~b}$ & $10.16 \mathrm{a}$ & $48.96 \mathrm{a}$ & $50.40 a$ & $21.00 \mathrm{~b}$ & $1.02 \mathrm{~b}$ & $16.90 \mathrm{c}$ & $8.16 b$ & $4.08 b$ & $0.40 \mathrm{~b}$ \\
\hline $\mathrm{A} 2 \mathrm{M} 10$ & $4.0 \mathrm{~b}$ & $6.97 c$ & $40.38 \mathrm{c}$ & $40.88 \mathrm{c}$ & $18.88 \mathrm{c}$ & $0.94 b$ & $15.42 \mathrm{C}$ & $8.50 \mathrm{a}$ & $3.76 b$ & $0.55 \mathrm{a}$ \\
\hline Mean & 4.1 & 8.61 & 44.7 & 44.98 & 20.24 & 0.96 & 16.13 & 8.22 & 3.86 & 0.46 \\
\hline
\end{tabular}

Means followed by the same lowercase letter in a column did not differ by the Scott Knott test $(p \leq 0.05)$.

The identification of a geographic structure in the dendrogram was not possible due to the lack of information about the origin of the genebank accessions. The segregation of accessions in Area 1 and Area 2 in the genebank plantation at Embrapa could be related to a distinct geographical origin of the groupings, yet no structure could be identified in the estimated dendrogram with relation to areas 1 and 2 . For a cutting point at a fusion level of 0.5861 , only two groups were obtained: group A contained 20 accessions, 14 of which were located in Area 1 of the genebank and 6 in Area 2. Analyzing the subgroups formed within group $A$, no pattern of position in the dendrogram was observed for accessions from Area 1 and Area 2. Group B was composed of three accessions of Area 2, and contained two subgroups, the first at 0.09\% of the total distance contained accessions A2M01 and 
$\mathrm{A} 2 \mathrm{M} 05$, and the second, at $0.14 \%$ of the total distance, contained only A2M04. Accessions A1M05 and A2M06 were grouped separately in groups C and D, respectively, at this fusion level.

Canonical correlation analysis resulted in $\mathrm{r}=0.6412\left(\mathrm{r}^{2}=\right.$ 0.4111 ) for the first pair, yet none of the three estimated pairs of super characters was significantly correlated, despite the low amplitude observed in the associations. AMOVA showed that the variance within assessions $(60.79 \%)$ was higher than the variance among accessions (39.21\%) (Table 2).
Our results showed that the selection would be more effective within accessions by selecting individuals from the same progeny, with a view to explore as much as possible the variation obtained in the expected segregation. Associations should be tested between other sets of traits than those analyzed in this study. To test the diversity between and within accessions by AMOVA, important data were generated for the adoption of strategies for improvement of the species. The cluster by Scott Knott test indicated significant variability among assessions for the analyzed traits, pointing to potential gains with selection.

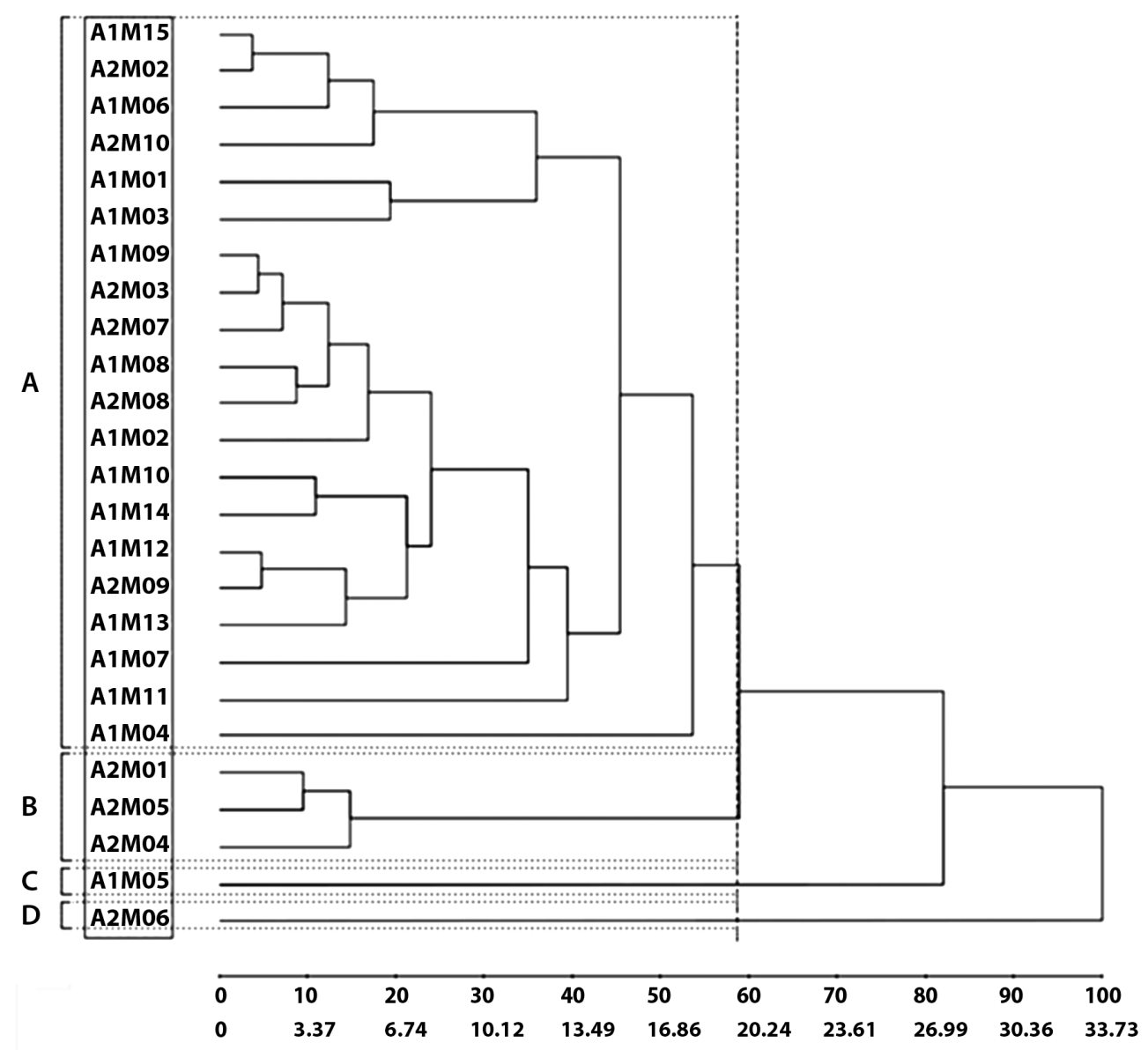

FIGURE 1. Dendogram of 25 accessions of Plukenetia volubilis estimated by the hierarchical grouping method UPGMA, the vertical dotted line represents the estimated cutting point by the method of Mojema $\left(0.5861^{*}\right)$ and $A, B C$ and $D$ are groups formed at this fusion level.

Table 2. AMOVA for accessions of Plukenetia volubilis, estimated from the dissimilarity matrix among the accessions and considering two hierarchical levels (among and within accessions).

\begin{tabular}{lccccc}
\hline Source of Variation & Degrees of Freedom & Sum of Squares & Mean Squares & Estimate of Variance Components & Percentage of Variation \\
\hline Among & 24 & 624.0000 & 26.0000 & 3.9714 & 39.21 \\
Within & 100 & 615.6800 & 6.1568 & 6.1568 & 60.79 \\
\hline Total & 124 & 1240.0029 & 10.0000 & & \\
\hline
\end{tabular}


Significant differences using this clustering method were observed in studies grouping means of sacha inchi matrices and in species of the Euphorbiaceae family (Lyra et al. 2012, Valente et al. 2017).

Canonical correlation analysis indicated that the fruit biometry traits are not reliable indirect parameters for seed selection, thus directly measured seed characters must be included in the selection analysis. However, since the main product of sacha inchi is oil, the production of highweight seeds is economically attractive, aiming at a higher productivity in agriculture. When choosing accessions for crosses, the dendrogram provides information that may be useful in the selection of matrices. We recommend that priority be given to the crossing of accessions among the different groups indicated in the dendrogram.

\section{ACKNOWLEDGEMENTS}

The authors thank the Coordenação de Aperfeiçoamento de Pessoal de Nível Superior CAPES), the Conselho Nacional de Desenvolvimento Científico e Tecnológico (CNPq) and Fundação de Amparo à Pesquisa do Estado do Amazonas (FAPEAM) for the financial support.

\section{REFERENCES}

Cruz, C.D. 2013. GENES - a software package for analysis in experimental statistics and quantitative genetics. Acta Scientiarum, 35:271-276.

Follegatti-Romero, L.A.; Piantino, C.R.; Grimaldi, R.; Cabral, F.A. 2009. Supercritical CO2 extraction of omega-3 rich oil from Sacha inchi (Plukenetia volubilis L.) seeds. The Journal of Supercritical Fluids, 49:323-329.

Lyra, D.H.; Almeida, L.A.H.; Brasileiro, B.P.; Santana, M.R.; Amaral, C.L.F. 2012 Genetic parameters of fruits, seeds and seedlings of Jatropha ribifolia (Pohl) Baill (Euphorbiaceae). Revista Brasileira de Plantas Medicinais, 14: 579-585.

Valente, M.S.F.; Chaves, F.C M.; Lopes, M.T.G.; Oka, J.M.; Rodrigues, R.A.F. 2017. Crop yield, genetic parameter estimation and selection of sacha inchi in central Amazon. Pesquisa Agropecuária Tropical, 47:226-236.

Villalobos, V.M.; Ferreira, P.; Mora, A. 1991. The use of biotechnology in the conservation of tropical germplasm. Biotech Advances, 9: 197-215.

RECEIVED: $07 / 08 / 2017$

ACCEPTED: 21/01/2018

ASSOCIATE EDITOR: Alexandre Pio Viana 